\title{
SETTING UP A GENE EXPRESSION STUDY FOR TISSUE CELLS BY METHOD OF QUANTITATIVE REAL-TIME PCR
}

\author{
Daliborka DUŠANIĆ ${ }^{1}$, Luka BOLHA ${ }^{1}$, Mojca NARAT ${ }^{1}$, Irena OVEN ${ }^{2}$
}

Received February 15, 2012; accepted June 10, 2012.

Delo je prispelo 15. februarja 2012, sprejeto 10. junija 2012.

\begin{abstract}
Setting up a gene expression study for tissue cells by method of quantitative real-time PCR

Gene expression analysis by quantitative reverse transcription polymerase chain reaction (RT-qPCR) allows accurate and sensitive measurment of gene expression levels. However, a series of steps needs to be taken to ensure the relevance, accuracy, correct interpretation and repeatability of the RT-qPCR experiment. We describe here a simple experiment of determining relative gene expression for caspase 8 gene in chicken chondrocytes treated with an apoptosis inducing compound 5-fluorouracil. We use this example to point out some important guidelines in setting up a gene expression study in tissue cells, analyzing and interpreting the results and reporting on the findings.
\end{abstract}

Key words: molecular genetics / RT-qPCR / gene expression / tissue cells

\section{INTRODUCTION}

The ability to monitor the real-time progress of the PCR completely revolutionized the way one approaches PCR-based quantitation of DNA and RNA. In comparison to clasical approach to PCR, where we detect the amount of PCR product accumulated after a fixed number of cycles, qPCR reactions are characterised by the point in time during cycling when amplification of a PCR product is first detected. This enables amplification and detection of as little as a single copy of a particular sequence. Theoretically, there is a quantitative relationship between amount of starting target sequence
Načrtovanje in izvedba študije genskega izražanja na tkivnih celicah $z$ uporabo metode kvantitativnega PCR $v$ realnem času Analiza izražanja genov $\mathrm{z}$ metodo reverznega pomnoževanja in kvantitativne verižne reakcije s polimerazo v realnem času (RT-qPCR) omogoča natančno in občutljivo določanje nivoja izražanja tarčnih genov. Vendar je za zagotavljanje točnosti, natančne interpretacije in ponovljivosti eksperimenta, predvsem pa relevantnosti rezultatov, pomembno natančno poznavanje korakov postopka. $\mathrm{V}$ tem prispevku opisujemo enostaven poskus, $\mathrm{v}$ katerem smo v celični liniji kokošjih hondrocitov, ki smo jih tretirali s spojino 5-fluorouracil, ki sproži apoptozo, določili relativno izražanje gena, ki kodira encim kaspazo 8. Ta primer smo uporabili za izpostavitev nekaterih pomembnih smernic pri oblikovanju študije izražanja genov v tkivnih celicah, analizi in interpretaciji rezultatov ter oblikovanju zaključkov.

Ključne besede: molekularna genetika / kvantitativni PCR v realnem času / gensko izražanje / tkivne celice

and amount of PCR product, detectable by the amount of fluorescence at any given cycle. The higher the starting copy number of the nucleic acid target, the sooner a significant increase in fluorescence is observed. By plotting the increase in fluorescence versus cycle number, the system produces amplification plots that provide a more complete picture of the PCR process than assaying product accumulation after a fixed number of cycles. Two types of chemistries have been developed to help product detection. In the intercalator based (Higuchi et al., 1992; Higuchi et al., 1993; Sabel et al., 2011), used in this experiment, fluorescence is produced after a small molecule binds to double-stranded DNA. This approach

1 Univ. of Ljubljana, Biotechncal Fac., Dept. of Animal Science, Groblje 3, SI-1230 Domžale, Slovenia

2 Same address, e-mail: Irena.Oven@bf.uni-lj.si 
is cheaper compared to the alternative, offers wider variability of usage due to lack of sequence specificity and yields a stronger fluorescence signal since more dye molecules can bind one target sequence. However, since DNA-binding dyes have no specificity, non-specific amplification due to mis-priming or primer-dimer artifacts also generates a signal, making it imperative to evaluate primers and disociation curves. In the fluorogenic probebased approach (Holland et al., 1991; Lee et al., 1993), only specific binding of the probe to the target sequence produces a fluorescent signal, enabling more specificity. Another advantage of probe-based assays is the possibility of labeling the probes with different, distinguishable reporter dyes, enabling detection of two or more distinct sequences in a single PCR reaction (multiplex). However, since different probes need to be synthesized for different sequences, the costs of this approach may be higher. Quantitation of the amount of target in unknown samples is accomplished by determining the Cq value and using it in one of the two methods of correlating $\mathrm{Cq}$ to template quantity. In the absolute quantification method, a standard curve is obtained by using known template concentrations and serves as basis for calculating the copy number from Cq. In the relative quantification method, used in this experiment, the expression of a target gene is calculated in comparison to a calibrator. In both methods, the expression of a target gene is normalized with reference to an internal control, or normalizer (Applied Biosystems User Bulletin \#2, 2001; Sabel et al., 2011).

RT-qPCR has proven itself as an useful tool for demonstrating alterations in gene expression in life sciences, agriculture and medicine. In addition to its use in research, many diagnostic applications have been developed, including microbial quantification, gene dosage determination, identification of transgenes in genetically modified foods, risk assessment of cancer recurrence, and applications for forensic use (Schnerr et al., 2001; Ahmed, 2002; Bernard et Wittwer, 2002; Mackay et al., 2002; Auer, 2003; Malorny et al., 2003; Mayer et al., 2003; Petit et al., 2003; Gachon et al., 2004; Bustin et Mueller, 2005; Morling, 2009). Ever since the method was introduced in 1992 (Higuchi et al., 1992; Higuchi et al., 1993), there has been a strong increase in the number of publications reporting RT-qPCR data, which invariably use diverse reagents, protocols, analysis methods and reporting formats. Yet, in spite of many parameters being subjectively set by the user, it was not untill 2009 that a consensus was published on how the experiment should be set properly and how should the results be presented to ensure trustworthiness of reported results, consistency between laboratories and experimental transparency (Bustin et al., 2009). The MIQE guidelines (Minimaum Information for Publication of Quantitative Real-Time
PCR Experiments) have been accepted as norm in many peer-reviewed journals and others will follow. In addition to these guidelines, a number of other corrections and modifications have been reported aiming to standardize intra-assay replicates (Willems et al., 2008), adjust current calculations to take into account different primer efficiencies (Pfaffl, 2001) or just customize the protocol for a specific area of diagnostics/research.

Hence, it is of great importance to be familiarized with the basic concepts of setting up a biological gene expression study by following the guidelines accepted as norm. In this paper, we describe a simple experiment set up to comply with the MIQE guidelines and address some common mistakes that hemper accurate quantification of target genes in a biological experiment. As an example, we use the analysis of caspase 8 expression alteration in primary chicken chondrocytes treated with 5 -fluorouracil, an apoptosis inducing compound (Backus et al., 2001).

\section{MATERIAL AND METHODS}

\subsection{CHICKEN CELLS}

Primary cultures of chicken chondrocytes $(\mathrm{CCH})$ were established from three chickens as described previously (Dušanić et al., 2009). CCH from different animals were cultivated separately in Dulbecco Modified Eagles Medium (DMEM), supplemented with 7,5\% fetal bovine serum (FBS) and 2,5\% chicken serum (all from SigmaAldrich). Cells were incubated at $37^{\circ} \mathrm{C}$ in a $5 \% \mathrm{CO}_{2}$ incubator up to the sixth passage.

\subsection{EXPERIMENTAL SETUP}

For gene expression analysis, a protocol described in Dušanić et al. (2012) was followed. CCH were seeded into $75 \mathrm{~cm}^{2}$ cell culture flasks (Techno Plastic Products) at density $5 \times 105$ cells $/ 10 \mathrm{ml}$ and incubated overnight at $37^{\circ} \mathrm{C}$ in a $5 \% \mathrm{CO}_{2}$ incubator prior to treatment. $\mathrm{CCH}$ were subsequently treated with 5-fluorouracil (5-FU, final concentration $20 \mu \mathrm{g} / \mathrm{ml}$, from Sigma-Aldrich) for $72 \mathrm{~h}$ and sampled by tripsinization. Cells isolated from one animal and treated with 5-FU, together with its nontreated control, represented one independent biological repeat of the experiment. 


\subsection{SAMPLE PREPARATION}

$\mathrm{CCH}$ were washed in sterile phosphate buffered saline, followed by isolation of total RNA using the RNeasy Mini Kit (Qiagen). RNA concentration was determined spectrophotometrically using NanoVue (GE Healthcare). Subsequently, RNA was stored at $-80^{\circ} \mathrm{C}$ to prevent degradation. Residual DNA was eliminated by incubating $1 \mu \mathrm{g}$ or RNA with $1 \mathrm{U}$ of DNase I in a buffer containing $\mathrm{MgCl}_{2}$ ions (both from Termo Fisher Scientific - Fermentas) for $30 \mathrm{~min}$ at $37^{\circ} \mathrm{C}$. Following DNase inactivation at $65^{\circ} \mathrm{C}$, cDNA was synthesized using a High-Capacity cDNA Reverse Transcription Kit (Life Technologies - Applied Biosystems), according to the manufacturers instructions. In order to test contamination with residual DNA, noreverse-transcription controls were performed for each experimental condition by omitting reverse transcriptase from the master-mix and subjecting the reaction mix to the same thermal cycler program for reverse transcription. cDNA and the controls were stored at $-20{ }^{\circ} \mathrm{C}$ immediately after reverse transcription.

\subsection{PRIMER SELECTION AND VALIDATION}

Primer pairs were designed in NCBI Primer-BLAST application, which is freely available on the web (http:// www.ncbi.nlm.nih.gov/tools/primer-blast/). Prior to use, they were checked for specificity in silico using the same application. Primer efficiency was checked in the following way. We prepared 10 -fold dilutions of cDNA combined from all experiments and experimental conditions. We used these cDNA mixes as templates in RT-qPCR reactions designed for all three primers selected in PrimerBLAST. Curves obtained by plotting Cq values to the $y-$ axis and log-transformed relative cDNA concentrations on the $\mathrm{x}$-axis served to calculate slopes. Efficiency was calculated from slopes as 10 $0^{-1 / \text { slope }}$ (Bustin et al., 2009).

\subsection{RT-QPCR ASSAY DESIGN}

We used a SYBR Green based assay, which is a cheaper and more versatile method for assaying gene expression compared to fluorogenic probes. For each assay, $20 \mu \mathrm{l}$ reaction mixtures were prepared, containing $10 \mu \mathrm{l}$ of Power SYBR Green PCR Master Mix (Life Technologies - Applied Biosystems), 0,5 $\mu \mathrm{l}$ of forward and 0,5 $\mu \mathrm{l}$ of reverse primer (final concentration $5 \mu \mathrm{M}$, Integrated DNA Technologies), $8 \mu$ of DEPC-treated water (Qiagen) and $1 \mu \mathrm{l}$ of cDNA. RT-qPCR reactions were performed on Stratagene Mx3000P (Agilent Technologies - Stratagene) and the amplification and dissociation plots analyzed in its MxPro software. The following experimental run protocol was used: initial denaturation step $\left(95^{\circ} \mathrm{C}\right.$ for 10 $\mathrm{min}$ ), amplification and quantification steps repeated 40 times $\left(95^{\circ} \mathrm{C}\right.$ for $30 \mathrm{~s}, 57^{\circ} \mathrm{C}$ for $1 \mathrm{~min}$ and $72{ }^{\circ} \mathrm{C}$ for 30 $\mathrm{s}$ with a single fluorescence measurement) and a melting curve step $\left(95^{\circ} \mathrm{C}\right.$ for $15 \mathrm{~s}, 57^{\circ} \mathrm{C}$ for $30 \mathrm{~s}$ and $15 \mathrm{~s}$ at $95^{\circ} \mathrm{C}$, continuous fluorescence measurement). We used GAPDH as a reference gene, based on its stability of expression and reported appropriateness for chondrocytes (Toegel et al., 2007; Dehne et al., 2010). Gene expression values of non-treated $\mathrm{CCH}$ were used for gene expression calibration. Appropriate controls were performed in each run: no template control, containing all reagents but cDNA in order to test possible contaminations of water, and no-reverse-transcription controls, obtained during reverse transcription to test possible contamination with residual genomic DNA.

\subsection{STATISTICAL ANALYSIS}

$\mathrm{CCH}$ obtained from three animals were treated with 5 -FU in separate experiments representing biological repeats and RNA from each experiment and experimental condition was analyzed separately. Three repeats of each RT-qPCR reaction were performed. Normalized relative quantities were obtained using the efficiency corrected (Pfaffl, 2001) $2^{-\Delta \Delta \mathrm{C}_{9}}$ method (Livak et Schmittgen, 2001). In order to exclude the effect of biological (intra-assay) variation on the statistical significance of results, log transformation of normalized relative quantities; mean centering and autoscaling were performed as described by Willems et al. (2008). Statistical significance of the results was determined using the unpaired Student t-test $(\mathrm{P}<0.05)$.

\section{RESULTS}

\subsection{CONFIRMATION OF PRIMER SPECIFICITY}

Primer pairs were designed to comply with general guidelines for designing primers for RT-qPCR. Hence, they were not longer than $25 \mathrm{bp}$, the predicted amplicon was not longer than $150 \mathrm{bp}, \mathrm{G} / \mathrm{C}$ content was not higher than $80 \%$, runs of identical nucleotides were avoided, $\mathrm{T}_{\mathrm{m}}$ of primers in one pair were no more than $2{ }^{\circ} \mathrm{C}$ apart and the five nucleotides at the 3 ' end had no more than two G and/or C bases (Sabel et al., 2011). All three primer pairs used in this study showed specificity for their target sequence in NCBI Primer BLAST. 


\subsection{INTERPRETATION OF AMPLIFICATION AND DISSOCIATION CURVES}

Next, amplification curves were studied. Baseline value was set to $1-2$ cycles before earliest amplification (evident by rapid increase in fluorescence). Threshold value was set in the linear, exponential phase of the amplification curve. These two values were set consistent

Table 1: The calculation of caspase 8 expression in CCH treated with 5-FU for $72 \mathrm{~h}$ relative to expression of caspase 8 in non-treated $\mathrm{CCH}$ (control 1, 2 and 3, representing 3 independent experiments and cells isolated from 3 different animals) and normalized to GAPDH expression as described in Material and methods

Preglednica 1: Izračun relativnega izražanja gena, ki kodira kaspazo $8 v$ CCH tretiranih za 72 hs 5-FU v primerjavi z izražanjem $v$ netretiranih CCH (control 1, 2 in 3, ki predstavljajo rezultate treh neodvisnih poskusov s celicami iz treh živali) in izražanjem normalizacijskega gena GAPDH, kot je opisano v poglavju Material in metode

\begin{tabular}{|c|c|c|c|}
\hline $\begin{array}{l}\text { Encoded protein } \\
\text { RefSeq mRNA number }\end{array}$ & & $\begin{array}{l}\text { caspase } 8 \\
\text { NM_204592.2 }\end{array}$ & $\begin{array}{l}\text { GAPDH } \\
\text { NM_204305_1 }\end{array}$ \\
\hline \multirow[t]{6}{*}{ Cq (raw data) } & control 1 & 20.59 & 13.95 \\
\hline & control 2 & 20.46 & 13.61 \\
\hline & control 3 & 20.14 & 13.83 \\
\hline & 5-FU 1 & 19.44 & 13.59 \\
\hline & 5-FU 2 & 19.94 & 14.41 \\
\hline & 5-FU 3 & 21.05 & 15.08 \\
\hline Primer efficiency $(\mathrm{E})$ & & 2.00 & 1.95 \\
\hline \multirow[t]{6}{*}{ Efficiency corrected ${ }^{1}$} & control 12 & $6.34 \mathrm{E}-07$ & $6.32 \mathrm{E}-05$ \\
\hline & control 22 & $6.96 \mathrm{E}-07$ & $8.02 \mathrm{E}-05$ \\
\hline & control 32 & $8.67 \mathrm{E}-07$ & $6.87 \mathrm{E}-05$ \\
\hline & 5-FU 1 & $1.4 \mathrm{E}-06$ & 8.09E-05 \\
\hline & 5-FU 2 & 9.97E-07 & $4.59 \mathrm{E}-05$ \\
\hline & 5-FU 3 & $4.61 \mathrm{E}-07$ & $2.88 \mathrm{E}-05$ \\
\hline \multirow[t]{6}{*}{ Divided mean average expression $^{2}$} & control 1 & 0.87 & 0.89 \\
\hline & control 2 & 0.95 & 1.13 \\
\hline & control 3 & 1.18 & 0.97 \\
\hline & 5-FU 1 & 1.92 & 1.15 \\
\hline & 5-FU 2 & 1.36 & 0.65 \\
\hline & 5-FU 3 & 0.63 & 0.41 \\
\hline \multirow[t]{6}{*}{ Normalized to GAPDH } & control 1 & 0.97 & 1 \\
\hline & control 2 & 0.84 & 1 \\
\hline & control 3 & 1.22 & 1 \\
\hline & 5-FU 1 & 1.67 & 1 \\
\hline & 5-FU 2 & 2.10 & 1 \\
\hline & 5-FU 3 & 1.54 & 1 \\
\hline \multirow[t]{2}{*}{ Average caspase 8} & control & 1.01 & l \\
\hline & $5-\mathrm{FU}$ & 1.77 & l \\
\hline \multirow[t]{2}{*}{ Standard deviation } & control & 0.19 & l \\
\hline & $5-\mathrm{FU}$ & 0.29 & l \\
\hline \multirow[t]{2}{*}{ Relative caspase 8 expression } & control & 1 & l \\
\hline & $5-\mathrm{FU}$ & 1.76 & l \\
\hline
\end{tabular}

$1=$ efficiency corrected values were calculated as E-DDCq; 2 = mean average expression was calculated by dividing each efficiency corrected value with the mean average efficiency corrected expression in control samples (non-infected $\mathrm{CCH}$, circled red) 
throughout all plates analyzed in the experiment. Dissociation curves of both caspase 8 and GAPDH primers showed no sign of non-specific transcripts or dimer formations (Fig. 2a and 2c), while one of the caspase 8 primers that showed specificity by Primer-BLAST, but with low efficiency (Fig. 1), was here confirmed as unusable for the experiment (Fig. 2b).

\subsection{REAL-TIME PCR AMPLIFICATION EFFICIEN- CIES AND LINEARITY}

We calculated primer efficiencies for all 3 primer pairs by determining the slope of the calibration curves. Primer pairs used in this experiment showed high efficiency, namely $95 \%$ for GAPDH and $100 \%$ for caspase 8 in the investigated dilution range and a high linearity $\left(\mathrm{R}^{2}>0.9\right)$ (Fig. 1). One of the primer pairs for caspase 8
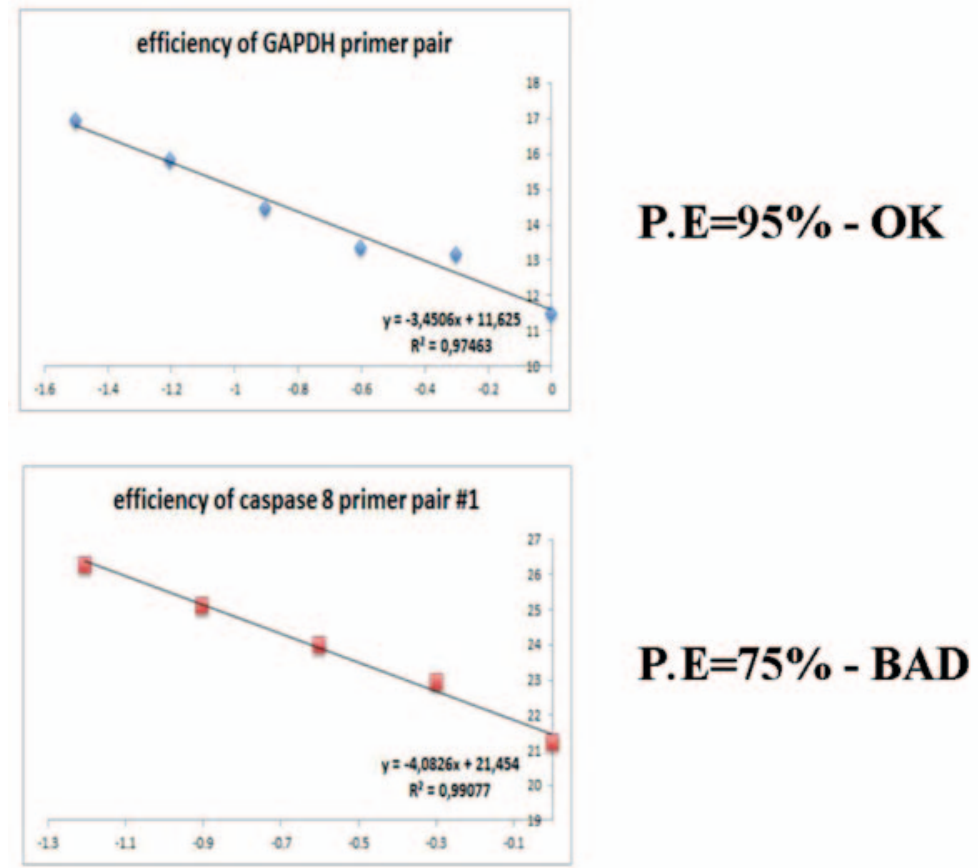

$P . E=95 \%-O K$

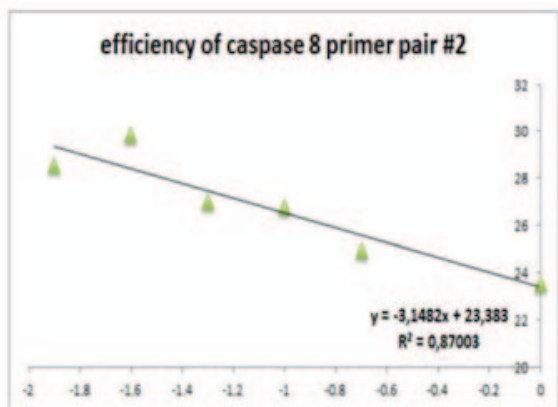

\section{$P . E=100 \%-O K$}

that showed specificity by Primer-BLAST demonstrated only $75 \%$ efficiency and was discarded (Fig. 1).

\subsection{RELATIVE QUANTIFICATION OF INVESTI- GATED GENE TRANSCRIPT}

The change in caspase 8 gene expression after treating $\mathrm{CCH}$ with 5 -FU for $72 \mathrm{~h}$ was determined by comparing its expression in treated and non-treated cells, normalized with regard to the GAPDH reference gene expression. Hence, the expression of caspase 8 in nontreated cells was used as calibrator, while the expression of GAPDH in all tested samples served for normalization. In order to take into account the amplification efficiencies, we applied the efficiency corrected $2^{-\Delta \Delta C q}$ method (Pfaffl, 2001). First, average Cq values were calculated from triplicates. Standard deviation between triplicates that was higher than $0,5 \mathrm{Cq}$ was not tolerated. Average $\mathrm{Cq}$ values were then corrected to reflect primer efficiency and the level of caspase 8 expression was normalized to GAPDH expression (Table 1). Relative caspase 8 expression was calculated by using the equation: ratio $=$ $\left(\mathrm{E}_{\text {target }}\right)^{\Delta \mathrm{CQtarget}(\text { control-sample) }} /\left(\mathrm{E}_{\text {ref }}\right)^{\Delta \mathrm{CQ} \text { ref(control-sample) }}$ (Pfaffl, 2001), where caspase 8 is the target, GAPDH the reference, non-infected $\mathrm{CCH}$ the control and $\mathrm{CCH}$ treated with 5-FU are the sample (Table 1). The relative expression of caspase 8 gene in $\mathrm{CCH}$ treated for $72 \mathrm{~h}$ with $5-\mathrm{FU}$ is shown in Fig. 3.

To exclude the impact of high variation between biological replicates, several standardization steps were performed. First, we performed a log transformation of the normalized relative gene expression levels, making the data distribution more symmetric. Next, we calculated mean expression levels of all conditions inside one replicate experiment and performed mean centering by dividing all normalized relative expression levels with the mean expression levels. This served as a correction for the differ-

Figure 1: Calibration curves for determination of primer efficiencies (P.E denotes primer efficiency as calculated from the slope). Primer specifity was validated by NCBI Primer-BLAST

Slika 1: Krivulje za določitev učinkovitosti pomnoževanja oligonukleotidnih začetnikov (P.E predstavlja učinkovitost oligonukleotidnih začetnikov, izračunano iz naklona premice). Specifičnost oligonukleotidnih začetnikov smo preverili v aplikaciji NCBI Primer-BLAST 
Table 2: Effect of sequential data transformation steps on the 95\% confidence interval (95\% CI, statistical significance) of differences between caspase 8 expression in non-treated CCH and CCH treated with 5-FU for $72 \mathrm{~h}$ (Willems et al., 2008)

Preglednica 2: Vpliv zaporednih korakov manipulacije s podatki na 95\% interval zaupanja (95\% CI) oz. statistično značilnost razlik v izražanju gena, ki kodira kaspazo 8 med netretiranimi CCH in CCH tretiranimi z 5-FU po 72 h (Willems in sod., 2008)

\begin{tabular}{|c|c|c|c|c|c|c|}
\hline \multirow{2}{*}{$\begin{array}{l}\text { Sequential data } \\
\text { transformation steps }{ }^{1}\end{array}$} & \multicolumn{3}{|c|}{ Untreated control } & \multicolumn{3}{|l|}{5 -FU for $72 \mathrm{~h}$} \\
\hline & Fold change & $-95 \% \mathrm{CI}$ & $+95 \% \mathrm{CI}$ & Fold change & $-95 \%$ CI & $+95 \% \mathrm{CI}$ \\
\hline None & 1 & 0.14 & 1.91 & 1.83 & 0.51 & 3.11 \\
\hline Log transformation & 1 & 0.62 & 1.60 & 1.76 & 1.19 & 2.61 \\
\hline + Mean centering & 1 & 0.65 & 1.53 & 1.76 & 1.15 & 2.69 \\
\hline+ Autoscaling & 1 & 1.00 & 1.00 & 1.76 & 1.76 & 1,76 \\
\hline
\end{tabular}

1 = Relative gene expression was first calculated for each experiment individually, as described in Table 2. For the log transformation, the formula $\log _{10}$ (fold change) was used on each experiment results individually. In the next step, averages for normalized gene expression were calculated for each experiment individually (including control and treated $\mathrm{CCH}$ ). Mean centering was performed by subtracting these averages from the individual normalized expression data within an experiment. Standard deviations within experiment were calculated from the mean centered data and used to divide every mean centered result with the standard deviation of the experiment in autoscaling. Autoscaling was corrected to reflect original experimental fold changes by multiplying the autoscaled values with the standard deviation of an individual experiment. We then calculated the averages, standard deviations and confidence intervals of these results across all 3 experiments, followed by correcting the results to linear form ( $10^{\text {average }}$ ) and recalculating the fold changes and confidence intervals (now for all 3 experiments together)

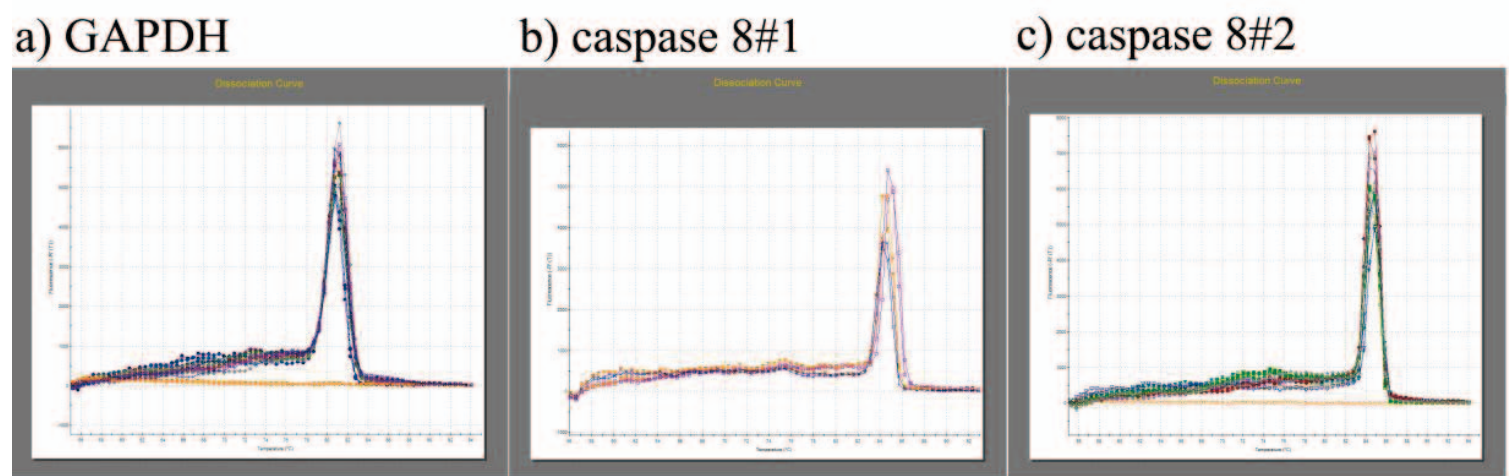

\section{d) calmodulin}

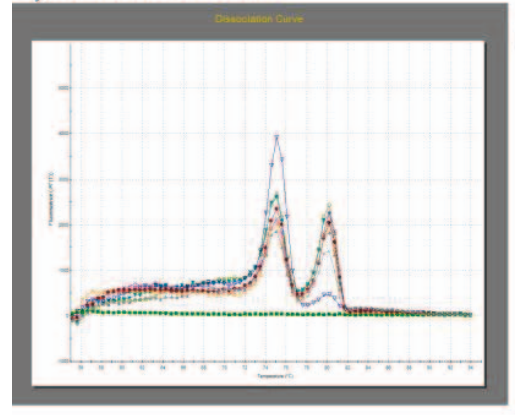

e) caspase 3

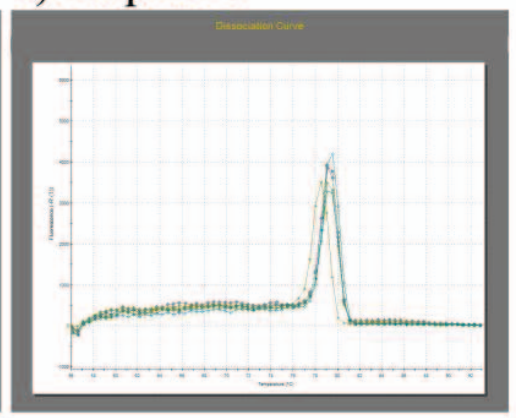

Figure 2: Primer pair choice, based on the shape of dissociation curves that were obtained by using a template prepared from 10-fold dilutions of cDNA mix from all experimental conditions. Dissociation curves for primers used in this experiment are shown in a) GAPDH, b) caspase 8, primer \#1 and c) caspase 8, primer \#2. The flat line indicating no fluorescence signal represents no-template control in all curves. Examples of primer dimers are shown in d) calmodulin, while a primer that needs additional confirmation before being used is shown in e) caspase 3 (note that not all peaks come together, as with the suboptimal primer \#1 for caspase 8 gene).

Slika 2: Izbira oligonukleotidnih začetnikov s preverjanjem oblike disociacijske krivulje, pripravljene iz 10-kratnih redčitev mešanice cDNA iz vseh eksperimentalnih pogojev. Disociacijske krivulje za oligonukleotidne začetnike uporabljene $v$ tem eksperimentu so a) GAPDH, b) kaspaza 8, prvi set začetnikov in c) kaspaza 8, drugi set začetnikov. Ravna linija, ki kaže odsotonost fluorescenčnega signala, predstavlja $v$ vseh primerih kontrolo kontaminiranosti vode. Primer tvorbe dimerov je pokazan $v d$ ) kalmodulin, medtem ko za začetnike e) kaspaza 3 potrebujemo dodano potrditev, saj se eden izmed signalov pojavi bistveno pred ostalimi (podobno kot pri prvih začetnikih za kaspazo 8) 
Table 3: Interpretations for some common difficulties with interpreting amplification curves (Sabel et al., 2011)

Preglednica 3: Pojasnitev vzrokov nekaterih pogostih težav, ki se pojavljajo med ocenjevanjem pomnoževalnih krivulj (Sabel in sod., 2011)

\begin{tabular}{|c|c|c|}
\hline Problem & Possible reasons & Solutions \\
\hline \multirow[t]{7}{*}{ No amplification } & Incorrectly set dye detector & Check instrument setting \\
\hline & Missing a master-mix component & Repeat experiment \\
\hline & Sample degradation & Synthesize new cDNA \\
\hline & Lack of target sequence & Confirm by using a positive control (plasmid) \\
\hline & Machine not calibrated for dye & Calibrate the machine \\
\hline & Incorrect baseline/threshold setup & Correct setup \\
\hline & $\begin{array}{l}\text { Probe degradation (in in assays using fluoro- } \\
\text { genic probes) }\end{array}$ & Check using positive control (plasmid) \\
\hline \multirow{5}{*}{$\begin{array}{l}\text { Unexpectedly low PCR efficiency } \\
(<85 \%)\end{array}$} & Incorrect dilutions of standards & Repeat experiment \\
\hline & Not enough dynamic range of standard curve & Use 10-fold dilutions \\
\hline & Primers designed for a SNP site & Design new primers \\
\hline & Instrument not calibrated for dye & Calibrate instrument \\
\hline & Sample inhibition & Repeat RNA/DNA isolation \\
\hline \multirow[t]{2}{*}{$\begin{array}{l}\text { Unexpectedly high PCR efficien- } \\
\text { cy }(>110 \%)\end{array}$} & Contamination with genomic DNA & $\begin{array}{l}\text { Treat RNA with DNase before reverse tran- } \\
\text { scription }\end{array}$ \\
\hline & Incorrect dilutions of standards & Use 10 -fold dilutions \\
\hline Positive no-template control & Contamination of DEPC-water & Repeat experiment \\
\hline $\begin{array}{l}\text { Positive no-reverse-transcription } \\
\text { control }\end{array}$ & Contamination with genomic DNA & $\begin{array}{l}\text { Treat RNA with DNase before reverse tran- } \\
\text { scription }\end{array}$ \\
\hline \multirow[t]{7}{*}{ Delayed Cq (after cycle 35) } & Decreased primer efficiency & *See unexpectedly low PCR efficiency \\
\hline & Low transcript expression & / \\
\hline & Sample inhibition & Synthesize new cDNA \\
\hline & Reaction interference (with multiplexing) & Optimize individual assays \\
\hline & Changed composition of master-mix & Be consistent within one experiment \\
\hline & $\begin{array}{l}\text { Low fluorescence dye intensity combined } \\
\text { with suboptimal instrument optics }\end{array}$ & Calibrate instrument \\
\hline & Baseline/threshold set incorrectly & Correct setup \\
\hline Early Cq (before cycle 15) & Too much template & Try setting baseline manually \\
\hline \multirow[t]{5}{*}{ Scattered replicates } & Pipetting inaccuracy & Repeat experiment \\
\hline & Poor thermal calibration in thermocycler & Calibrate instrument \\
\hline & Denaturation time too short & Try using longer denaturation time \\
\hline & Low copy number & / \\
\hline & Incorrectly set baseline & $\begin{array}{l}\text { Set baseline (in linear view) } 1-2 \text { cycles before } \\
\text { earliest amplification }\end{array}$ \\
\hline \multirow[t]{4}{*}{ Unusually shaped curves } & Sample evaporation & Check volume of sample after reaction \\
\hline & $\begin{array}{l}\text { Too much probe (in assays using fluorogenic } \\
\text { probes) }\end{array}$ & Optimize probe concentration \\
\hline & Instrument not calibrated for dye & Calibrate instrument \\
\hline & Dye interference (in multiplex assays) & $\begin{array}{l}\text { Optimize dye calibration and master-mix } \\
\text { composition }\end{array}$ \\
\hline
\end{tabular}


ence in background or control level between biological repeats. Next, standard deviation of mean centered data was calculated and used in autoscaling or equalization of the standard deviation across all conditions inside one biological replicate. We performed this by dividing mean-centered values with the experimental standard deviation for the same biological replicate. Autoscaling required a final correction of the fold change by multiplying the autoscaled fold changes with the mean standard deviation of the replicate experiments before autoscaling so as to make the fold changes reflect the initial observations, resulting in standardized and fold-change preserved log-transformed relative quantities (Willems et al., 2008). Student t-test, performed on standardized fold changes, resulted in statistical significance of alterations in caspase 8 expression in $\mathrm{CCH}$, followed by 72 h treatment with 5-FU (Table 2, Fig. 3).

\section{DISCUSSION}

Reverse transcription followed by quantitative polymerase chain reaction analysis, or RT-qPCR, is an extremely sensitive and cost-effective method for quantifying gene transcripts. However, a series of steps in setting up a biological gene expression study using this method are influenced by the researcher, hence subjective. In order to ensure the trustworthiness of reported results, consistency between laboratories and experimental transparency, MIQE guidelines were proposed in 2009 and are becoming the norm for publishing results obtained by qPCR.

In this paper we described a simple experiment, in which we determined the expression of caspase 8 gene in chicken chondrocytes treated for $72 \mathrm{~h}$ with 5 -FU, an apoptosis-inducing compound (Backus et al., 2001). We used this example to point out some general guidelines in setting up a gene expression study on tissue cells and some factors that influence the objectivity of results obtained by RT-qPCR.

As stressed by MIQE, assay performance is most affected by the following technical deficiencies: i) inadequate sample storage, preparation and nucleic acid quality; ii) poor choice of reverse-transcription primers and probes; and iii) inappropriate data and statistical analyses, altogether generating results that can be highly misleading. An additional problem in life science research is the variation between biological replicates, leading to inacurate assessment of statistical significance of differences in spite of clear biological effect in each replicate (Willems et al., 2008).

In order to address the problem of biological relevance in the experiment, $\mathrm{CCH}$ isolated from 3 different chickens were used, representing 3 biological replicates of the experiment. Following $72 \mathrm{~h}$ of treatment with 5 -FU supplemented growth medium, RNA was isolated sepa-

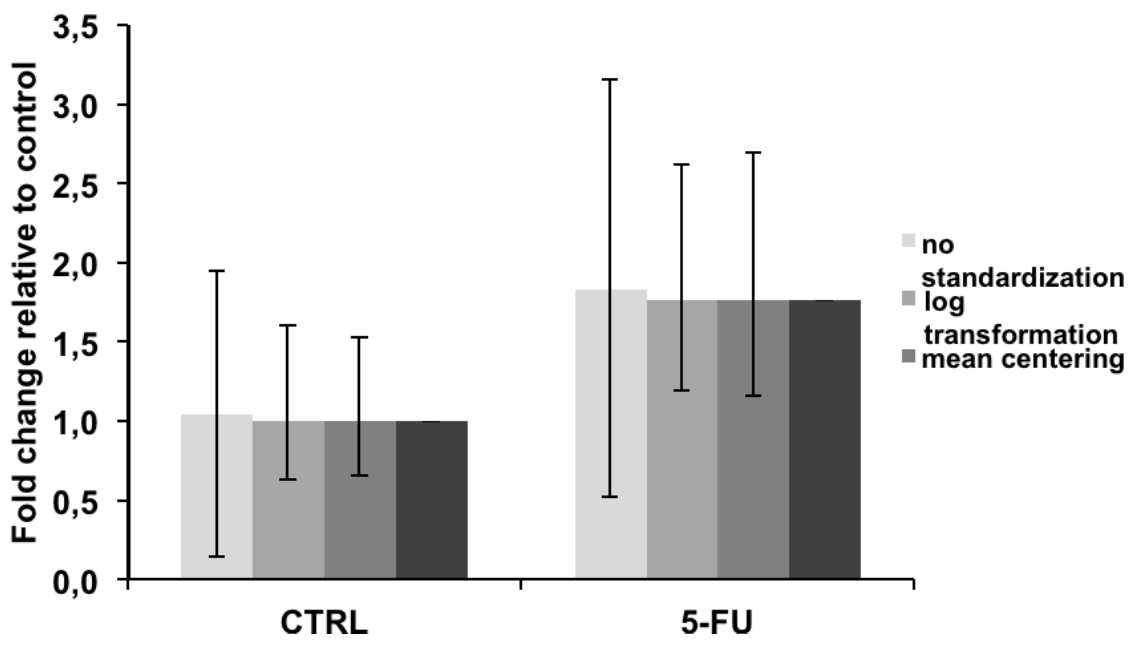

Figure 3: Effect of sequential data transformation steps, aimed to standardize the results and limit the influence of intra-experimental (biological) variation on statistical significance of caspase 8 expression differences between CCH treated with 5-FU and non-treated cells (CTRL). Results are presented as average fold change and 95\% confidence intervals. LT represents log transformation; MC is mean centering and AS autoscaling.

Slika 3: Vpliv zaporednih korakov manipulacije s podatki za standardizacijo rezultatov in omejevanje vpliva biološke variabilnosti na interval zaupanja oz. statistično značilnost razlik v izražanju gena, ki kodira kaspazo 8, in sicer med netretiranimi CCH (CTRL) in CCH tretiranimi s 5-FU. Rezultati so podani kot povprečna relativna sprememba $z$ ustreznimi 95\% intervali zaupanja. LT predstavlja logaritemsko transformacijo, MC centriranje povprečij in AS izenačevanje standardne deviacije v vseh eksperimentalnih pogojih znotraj ene ponovitve 
rately for each biological replicate. All relevant data on how RNA samples were obtained and kept, transcribed to cDNA and analyzed are indicated in the results section.

A detailed report on how primer pairs were chose and the specificity of target binding confirmed is described in Material and methods. In addition, we report on both primer specificities, based on dissociation curves (Fig. 1 and 2). The shape of the dissociation and amplification curve is an important indicator of the analysis, and can point out to several technical oversights or poor assay/primer design. The shape of the amplification curve gives insight to possible mistakes in setting up the experiment (Table 3), while the shape of the dissociation curve gives information about the specificity of the primer pair. It is essential to check for dimer formations, since these give a false positive signal in the SYBR Green based assays that are less specific than assays based on fluorescence probes. Fig. 2 shows disociation curves for both primers used in this experiment, as well as examples of less optimal primers. Optionally, the size of the amplified sequence can be checked by agarose gel electrophoresis, in cases when the amplification and dissociation curves are ambiguous. Shorter sequences indicate formation of non-specific amplification products, such as primer-dimers.

Primer pair efficiency should always be checked prior to analysis in a biological experiment. Primer pairs that show efficiency $<85 \%$ should not be used. In some cases, optimizing both forward and reverse primer concentrations, increasing the annealing temperature and shortening of the annealing time can lead to less nonspecific primer binding and reduce the formation of dimers, making the pair usable. Primer efficiencies for both GAPDH and caspase 8 were checked in this experiment and are shown in Fig. 1. Based on poor efficiency, as well as ambiguous dissociation curve, primer pair \#1 for caspase 8 was excluded from the analysis (Fig. 1 and 2).

After we choose the optimal and most efficient primer pair, we can analyze the expression of our genes of interest. In this study, we determined the relative gene expression for the apoptotic gene caspase 8 in comparison to GAPDH internal control or normalizer. This was calculated using the efficiency corrected $2^{-\Delta \Delta C q}$ method (Pfaffl, 2001) that takes into account the differences between primer efficiencies for the target and reference gene (Table 1). Taking into account the great biological variability that is inevitable in such experiments, additional transformation steps were performed on the data. In Fig. 3 and Table 2, we showed how a series of simple data transformation steps can lead to standardization of highly variable biological repeats and narrowing of confidence intervals. This can facilitate statistical evaluation of findings and help in drawing relevant conclusions. Our results demonstrate obvious reduction in the 95\% confidence interval of fold changes, giving the data more credibility and giving insight into signaling events that follow treatment of $\mathrm{CCH}$ with 5-FU (Table 2, Fig. 3). We can conclude with great certainty that treating chicken chondroctes with 5-FU induces upregulation of caspase 8 gene. Since the caspase 8 enzyme encoded by this gene belongs to the group of initiator caspases, its upregulation indicates activation of programmed cell death in treated $\mathrm{CCH}$. However, since apoptosis is a complex series of events and signalling pathways, confirming this hypothesis would require analysis of other apoptotic genes, as well as performing other assays, such as immunodetection of relevant proteins. Nevertheless, gene expression is the first and easyest step in decyphering the events in a cell.

With this example, we showed the potential of RTqPCR in life science research. Obviously, the ability to precisely detect relative changes in gene expression is a valuable tool for studying any number of physiological, pathophysiological and developmental models. Thus, if used in compliance with generally accepted guidelines of assay standardization, RT-qPCR can be a powerful first step in many research projects in addition to its usefulness in diagnostics.

\section{CONCLUSIONS}

Setting up a gene expression study involving tissue cells requires carefulness in considering the level of biological variability by choosing the proper statistical test. Also, it is of key importance to ensure adequate primer choice, choice of protocols for RNA isolation and storage and to set up a good RT-qPCR assay. If performed consistently and in compliance with some generally accepted guidelines, termed MIQE, this method allows rapid, accurate and sensitive determination of gene expression levels and relevant and repeatable results. In this paper, we used a simple example to describe some most important steps in setting up a biological gene expression study and pointed out some of the factors that influence the interpretation of results.

\section{SKLEPI}

Pravilno načrtovanje in izvedba študije izražanja genov $\mathrm{v}$ tkivnih kulturah oz. celičnih linijah zahteva upoštevanje biološke variabilnosti pri izbiri statističnega testa, pravilno izbiro oligonukleotidnih začetnikov, protokolov izolacije in shranjevanja genskega materiala, 
protokola analize genskega izražanja s pomočjo metode reverznega pomnoževanja in kvantitativne verižne reakcije s polimerazo v realnem času (RT-qPCR). Če je pravilno izvedena, metoda omogoča hitro, natančno in občutljivo določanje nivoja izražanja tarčnih genov. Za zagotavljanje točnosti, natančne interpretacije in ponovljivosti takšnega eksperimenta, moramo slediti priporočilom MIQE. V prispevku smo na preprostem primeru opisali najpomembnejše korake pri načrtovanju in izvedbi biološke študije izražanja genov in izpostavili nekatere faktorje, ki lahko vplivajo na končne rezultate.

\section{REFERENCES}

Ahmed F.E. 2002. Detection of genetically modified organisms in foods. Trends in Biotechnology, 20: 215-223

Applied Biosystems User bulletin \#2: ABI Prism Sequence Detection System. 1997 (updated 2001): 36 p.

Auer C.A. 2003. Tracking genes from seed to supermarket: techniques and trends. Trends in Plant Science, 8: 591-597

Backus H.H.J., Dukers D.F., van Groeningen C.J., Vos W., Bloemena E., Wouters D., van Riel J.M.G.H., Smid K., Giaccone G., Pinedo H.M., Peters G.J. 2001. 5-fluorouracil induces Fas upregulation associated with apoptosis in liver metastases of colorectal cancer patients. Ann Oncol, 12: 209-216

Bernard P.S., Wittwer C.T. 2002. Real-time PCR technology for cancer diagnostics. Clin Chem, 48: 1178-1185

Bustin S.A., Mueller R. 2005. Real-time reverse transcription PCR (qRT-PCR) and its potential use in clinical diagnosis. Clin Sci (Lond), 109: 365-379

Bustin S.A., Benes V., Garson J.A., Hellemans J., Huggett J., Kubista M., Mueller R., Nolan T., Pfaffl M.W., Shipley G.L., Vandesompele J., Wittwer C.T. 2009. The MIQE guidelines: Minimum Information for Publication of Quantitative Real-Time PCR Experiments. Clinical Chemistry, 55: 611-622

Dehne T., Schenk R., Perka C., Morawietz L., Pruss A., Sittinger M., Kaps C., Ringe J. 2010. Gene expression profiling of primary human articular chondrocytes in high-density micromass reveals patterns of recovery, maintenance, re- and dedifferentiation. Gene, 462: 8-17

Dušanić D., Berčič R.L., Cizelj I., Salmič S., Narat M., Benčina D. 2009. Mycoplasma synoviae invades non-phagocytic chicken cells in vitro. Veterinary Microbiology, 138: 114-119

Dušanić D., Benčina D., Oven I., Cizelj I., Benčina M., Narat M. 2012. Mycoplasma synoviae induces upregulation of apoptotic genes, secretion of nitric oxide and appearance of an apoptotic phenotype in infected chicken chondrocytes. Veterinary Research, 43: 7

Gachon C., Mingam A., Charrier B. 2004. Real-time PCR: what relevance to plant studies? Journal of Experimental Botany, 55: 1445-1454
Higuchi R., Dollinger G., Walsh P.S., Griffith R. 1992. Simultaneous amplification of specific DNA sequences. Biotechnology, 10: 413-417

Higuchi R., Fockler C., Dollinger G., Watson R. 1993. Kinetic PCR: Real time monitoring of DNA amplification reactions. Biotechnology, 11: 1026-1030

Holland P.M., Abramson R.D., Watson R., Gelfand D.H. 1991. Detection of specific polymerase chain reaction product by utilizing the 5' to 3' exonuclease activity of Thermus aquaticus DNA polymerase. Proceedings of the National Academy of Sciences USA, 88: 7276-7280

Lee L.G., Connel C.R., Bloch W. 1993. Allelic discrimination by nick-translation PCR with fluorogenic probes. Nucleic Acids Research, 21: 3761-3766

Livak K.J., Schmittgen, T.D. 2001. Analysis of relative gene expression data using real-time quantitative PCR and the $2^{-\Delta \Delta \mathrm{Cq}}$ method. Methods 25: 402-408

Mackay I.M., Arden K.E., Nitsche A. 2002. Real-time PCR in virology. Nucleic Acids Research, 30: 1292-1305

Malorny B., Tassios P.T., Radstrom P., Cook N., Wagner M., Hoorfar J. 2003. Standardization of diagnostic PCR for the detection of foodborne pathogens. Int J Food Microbiol, 83: 39-48

Mayer Z., Bagnara A., Färber P., Geisen R. 2003. Quantification of the copy number of nor-1, a gene of the aflatoxin biosynthetic pathway by real-time PCR, and its correlation to the cfu of Aspergillus flavus in foods. International Journal of Food Micribiology, 82: 143-151

Morling N. 2009. PCR in forensic genetics. Biochem Soc Trans, 37: $438-440$

National Center for Biotechnology Information/PrimerBLAST. http://www.ncbi.nlm.nih.gov/tools/primer-blast/.

Petit L., Baraige F., Balois A.M., Bertheau Y., Fach P. 2003. Screening of genetically modified organisms and specific detection of Bt176 maize in flours and starches by PCR-enzyme linked immunosorbent assay. Euroean Food Research and Technology, 217: 838-853

Pfaffl M.W. 2001. A new mathematical model for relative quantification in real-time RT-PCR. Nucleic Acids Research, 29: 2002-2007

Sabel J., Gunstream S., Menezes A., Owens B., Rose S. 2011. qPCR Application Guide. Edited by Sabel J. Integrated DNA technologies: 73 p.

Schnerr H., Niessen L., Vogel R.F. 2001. Real time detection of the tri5 gene in Fusarium species by LightCycler ${ }^{\mathrm{TM}}$-PCR using SYBR'-Green I for continuous fluorescence monitoring. International Journal of Food Microbiology, 71: 53-61

Toegel S., Huang W., Piana C., Unger F.M., Wirth M., Goldring M.B., Gabor F., Viernstein H. 2007. Selection of reliable reference genes for qPCR studies on chondroprotective action. BMC Molecular Biology, 8: 13

Willems E., Leyns L., Vandesompele J. 2008. Standardization of real-time PCR gene expression data from independent biological replicates. Analytical Biochemistry, 379: 127-129 